DOI: 10.20472/BMC.2018.008.005

\author{
SARAH RANJANA GÜSKEN \\ Institute for Management Cybernetics at RWTH Aachen, Germany
}

\title{
EXPANDING TO ONLINE PLATFORM BUSINESS MODELS FOR GROCERY RETAILERS - INSIGHTS FROM CASE STUDIES
}

\begin{abstract}
:
This paper examines the requirements of German, owner managed grocery retailers when expanding their business model by including online platforms to their distribution channels. Fourteen guided interviews with German grocery retailers were conducted, focusing on the status quo of their business models as well as their individual needs when it comes to online distribution. The contribution with this paper are twofold. First, we provide practical insights from real case studies in the way business models from small and medium enterprises in grocery retailing are structured. Second, we point out technological and non-technological requirements when small grocery retailers try to change their business model concerning to the engagement in online platforms. The paper finishes with suggestions on opportunities how to address these requirements.
\end{abstract}

\section{Keywords:}

Business Model Innovation, Business Models, Platform Models, Case Study, Retail, Grocery Retail, Retailer Requirements, Online Grocery Retail

JEL Classification: $032,033,052$ 


\section{Introduction}

Over the last years, we saw the successful integration of e-commerce via digital platform concepts in industries, like electronics, books or clothing in Germany. In contrast, the German online grocery sector does not equally profit from the advantages of platform scales yet. Other industries showed that these advantages can incorporate huge sales growth and enable competitiveness in the future. Digital online shopping platforms as part of a business and organizational model are forming the basis for the successful development of today's most powerful companies e.g. Amazon, Google, Uber etc. They are not only transforming entire economic structures but also affect social and technological developments. Being the leading business model in terms of economic, social and technological impacts, they allow companies from diverse industries to be prosperous (Parker, Alstyne \& Choudary 2016). Therefore, it is of particular interest why especially in the grocery industry the platform model did not assert itself in Germany until now. More precisely, it is an interesting development, why the platform model has not found its application with small, owner managed regional grocery retailers, since they are seriously threatened by the market power of big players like Edeka, Rewe, Aldi and others. In economic terms, the German grocery sector constitutes an interesting market since $35.8 \%$ of the entire retailing purchasing power are situated in this industry. The share of online retailing in 2016 still only stands at $1 \%$, which is due to the size of this market with a total revenue of 1.72 billion euro. Only a few small and stationary grocery retailers extended their traditional business by the aspect of e-commerce. This leaves the major share of online and offline sales to the mentioned big players (Handelsverband Deutschland 2017; Bettina Borchmann 2018) and is resulting in the disappearance of small and regional grocery retailers. In order to assert the position of small, regional and owner managed grocery retailers it is necessary to understand their ambitions, limitations and abilities of their current business models.

The present work surveys the status quo of the business models of small owner managed German grocery retailers. We investigate the motivation, ability and requirements of German grocery retailers to open their traditional business model to online platform concepts in order to stay competitive. We recognized that online grocery retailers realize a tremendous changing process in their market as well as a shift in consumer requirements regarding online shopping, while being unable to satisfy the digital consumer needs.

With this paper, we contribute in filling the research gap with the understanding under which conditions and requirements small grocery retailers are able to adapt their traditional business and participate in an online platform. We therewith help to understand current business models in the grocery retail sector, their strength, weaknesses and common features. We contribute in analysing business models which are still not 
understood sufficiently in regard to their real business activity and function (Linder \& Cantrell 2000; Osterwalder, Pigneur \& Tucci 2005; Chesbrough 2007; Chesbrough 2010), by investigating real existing retail businesses in the German grocery sector. Therefore, the main research questions of this study are:

(1) What is the current status quo of small owner managed grocery retailer's business models in Germany?

and

(2) Which requirements do small owner managed German grocery retailers have, when engaging in digital platforms?

To answer the research questions, guided interviews have been conducted with German retailers. In the following, the underlying methodology is introduced. Subsequently, the findings of the interviews are presented and discussed. Suggestions on how to meet the exposed retailer requirements are given. Finally, the paper gives an outlook on further research.

\section{Literature Review}

Contemplating the global development of the online grocery market provides a differentiated picture. With an online grocery share of only $1 \%$ the German online grocery market is far less developed compared to other countries. Underlining the realization, that especially for Germany research has to be undertaken in order to promote further development. In their study observing the French grocery market, Cervellon, Sylvie and Ngobo state, that in the last 15 years grocery retailing in France has significantly changed from the traditional stationary trading to city stores, home delivery and especially to the so-called "drive-models". Drive-models can be described as click and collect business model. With this, customer arrange their groceries online and pick them up at special drive through stations. In France in 2015 the drive-model constituted for $2.3 \%$ of all FMCG (fast moving consumer goods) (Cervellon, Sylvie \& Ngobo 2015). In the UK Suel, Le Vine \& Polak also explore a sustained shift of retail activity away from traditional stationary shopping toward buying groceries online. They state, that in $2013,5.1 \%$ of the grocery spending were progressed online, while in 2010 it only depicted for $3.8 \%$, demonstrating the fast growth of this market (Suel, Le Vine \& Polak 2015). Kang et al. state that the online grocery market is predicted to grow up to $12 \%$ by 2020 (Kang et al. 2016).

Likewise, the grocery market outside Europe is experiencing a shift from traditional stationary trading towards multi-channel and online business models. In the US the number of store-based retailers that add an online store to their portfolio is increasing. Not least due to the rise of the total online grocery spendings that stood in 2014 at $3.3 \%$. 
and the expectation of the total spending on online grocery to rise up to $11 \%$ till 2023 (Melis et al. 2015; Moriuchi \& Takahashi 2018).

Investigating the Japanese market, the online grocery market is far ahead in terms of online shopping. Moriuchi \& Takahashi state, that with Japan being an internet-driven society online shopping for grocery are at the core of shopping behaviour. In Japan it is not about how to enforce online grocery retailing, it is about how consumers advertise products and experiences via word of mouth platforms and how to use their endeavours for marketing purposes (Moriuchi \& Takahashi 2018).

All investigated studies in this context have in common, that consumers increasingly transact with retailers through different channels and formats. They declare that extra online services such as online shops are increasing customer satisfaction and therewith customer loyalty. Stating this, retailers need to engage in more channels and especially in online channels to enable sustainable success (Cervellon et al. 2015; Melis et al. 2015; Suel et al. 2015). Kang et al. therefore suggest, that grocers need to engage in strategic marketing efforts including diversified marketing strategies to consumer groups and product categories (Kang et al. 2016).

In the past years value creation has experienced a shift from traditional pipeline business models to platform structures (Choudary 2015; Parker et al. 2016; Van Alstyne). "Pipelines" traditionally have been one of the most dominant business designs, where firms produce and sell products to customers (Choudary 2015; Van Alstyne et al. 2016). Thereby, the value is created upstream while the consumption of them runs downstream, resulting in a linear value flow, just like water through a pipe (Choudary 2015).

In platform structures consumers producers, and the platform itself are connected to perform business actions by using the, via the platform provided, resources. Platform participants such as producers or consumers are able to exchange value with each other (Hagiu 2009; Choudary 2015). In contrast to the traditional pipeline, which is following a straight process from producer to consumer, value on platforms can be created, exchanged and consumed in different ways, depending on the resources of the platform. As the platform gather more customers, more retailers will be attracted to participate (Parker et al. 2016). Consumers as well as retailers thereby create values by selling and purchasing products, resulting in a phenomenon called "network effects" (Church \& Gandal 1992; Hagiu 2009; Parker et al. 2016). This effect corresponds to the size of the network, inducing the fact that successful platforms should expand quickly in size (Church \& Gandal 1992; Parker et al. 2016).

When expanding in size, the value of the platform especially expands due to the collection of customer information. With this, targeted customer marketing becomes possible and enhances the impact of marketing activities while resulting in higher profits (lyer, Soberman \& Villas-Boas 2005). Especially costumers with high loyalty increase 
their purchase when advertising increases (Raj 1982). Customer-centric marketing, which can especially be applied when explicit knowledge about the customers shopping behaviour is available, also provides the option of efficient and effective advertising, which in turn leads to higher profits (Sheth, Sisodia \& Sharma 2000).

Engaging in online shopping, Platforms can be seen as one way of cross-channel integration, where customers purchase products in-store as well as online. It allows customers to gather information via diverse channels, and therefore reduces the information asymmetry in terms of retailer and products. Cross channel integration also provides customers the convenience and freedom to shop via different channels in different situations (Cao \& Li 2015). It allows customers to perceive additional services such as in-store pickup, where the products are ordered online and subsequently collected in-store.

The platform concept has proven to be a successful model in the retailer market transition caused by the digitalisation. One firm after another follows the revolution of platforms (Gawer \& Cusumano 2008). Companies that are using the platform concept like Amazon, Google, Facebook or Uber are some of the fastest scaling businesses in the last decade (Gawer \& Cusumano 2008; Parker et al. 2016). The 176 largest platform companies, that were analysed in 2016 by Evans and Gawer, account for a total value of 4.4 Trillion USD. This illustrates the huge potential of platforms for the international economy (Evans \& Gawer 2016). Despite the huge potential of platforms, they have not pushed through in the German grocery market. The reasons for this still have to be investigated, since it offers great opportunities to the retailing structure.

Past researches mainly focused on consumer's online purchase behaviours (Akhter 2012) and shopping motivations (Ganesh et al. 2010). Furthermore, platform success is usually considered from the consumer's point of view only. Until now, research in this area does not refer to requirements that retailers have when it comes to the success of grocery online shopping platforms. Instead, they refer to e-service and online service quality of the retailers, which are recognized to be an important aspect in building competitive advantage (Chiou, Lin \& Perng 2011; Tontini et al. 2018).

\section{Methodology}

In respect to the research questions semi-structured open-ended questions in guided personal interviews were conducted. The interviews served the aim to assess the current business models of small owner managed grocery retailers in Germany and their corresponding technological and non-technological requirements when adapting and expanding to an online shopping platform concept.

The interview questions were chosen on the basis of e-commerce literature on technological and non-technological requirements to websites and online shops in other 
industries (Jones et al. 2000; Bhaskaran et al. 2001; Lefebvre \& Lefebvre 2002) (see table 1), and on the basis of the elements of a business model by Gassmann et al. (Gassmann, Frankenberger \& Csik 2013). Ex-ante interviews with three experts in the area of e-commerce were conducted, in order to point out important information on technological and non-technological factors as well as business model insights when it comes to the practical implementation of e-commerce platforms. The interviewed experts originate from different fields of expertise in the e-commerce sector, namely logistics, business intelligence as well as the programming and operation of e-commerce platforms. The ex-ante interviews were conducted via personal interviews, followed by the request to formulate the described requirements in a summarised written form. The resulting guideline for the retailer interviews consists of 33 questions in total, they relate to the following themes (i) Customer, (ii) Products \& Management, (iii) Delivery and (iv) System.

The recorded interviews were transcribed and grammatical errors as well as unsubstantial phrases were left out. The summarizing content analysis by Mayring (Mayring 2010) was chosen to structure the data, due to its suitability regarding the analysis of large quantities of text. With this method, individual sentences in the transcripts are reduced in two steps. In the first step, which is called paraphrasing, the transcribed sentences are transformed into the same level of language, correcting syntax errors and leaving out passages, which transport no or little content. These paraphrases are in a second step subsequently generalized by discarding contents, which are not relevant for answering the research questions.

Therefore, the process of generalization reformulates the sentences into shorter expressions, the reduced forms (Mayring 2010). The reduced forms are then assigned to categories (Flick 2014) belonging either to the status quo of the business models, or technological or non-technological requirements. Each general category is further characterized by subcategories (Mayring 2010). Table 1 gives an overview about the literature basis, the general categories, subcategories as well es some exemplary quotes from the interviews and their category classification.

Limitations of this study can be seen in the small sample size. In order to obtain grounded theory insides, the sample size has to be enlarged to 20 to 30 interviews. This study is classified as a single case study, which is especially applicable in German cities of the same size and retail structure. Furthermore, due to the resemblance of the interview results, the extracted data can be seen as saturated (Eisenhardt 1989; Marshall et al. 2013). 


\section{Table 1 Literature and Definition of Thematic Categories}

\begin{tabular}{|c|c|c|c|c|}
\hline Literature & $\begin{array}{l}\text { General } \\
\text { category }\end{array}$ & $\begin{array}{l}\text { Definition of } \\
\text { the general } \\
\text { category }\end{array}$ & Subcategory & Exemplary quotes \\
\hline $\begin{array}{l}\text { An e-business } \\
\text { integration and } \\
\text { collaboration } \\
\text { platform for } \\
\text { B2B e- } \\
\text { commerce } \\
\text { Bhaskaran et } \\
\text { al., } 2001\end{array}$ & $\begin{array}{l}\text { Business } \\
\text { process } \\
\text { integration }\end{array}$ & $\begin{array}{l}\text { Integration of } \\
\text { legacy } \\
\text { systems, ISV } \\
\text { applications, } \\
\text { users and } \\
\text { trading partners }\end{array}$ & $\begin{array}{l}\text { Recent ordering } \\
\text { system } \\
\text { Vendor }\end{array}$ & $\begin{array}{l}\text { "Two butcher shops, I say one and a half butchers, one and a half bistros, to date, could } \\
\text { change next year." } \\
\text { "I have a large wholesale who also provides the cheese. They collect the cheese from } \\
\text { small farmers over the whole week and brings it to me." } \\
\text { "Only online. I will not have a stationary retail, I've dealt with it intensively, I believe that } \\
\text { it is not worth it." }\end{array}$ \\
\hline $\begin{array}{l}\text { E-commerce } \\
\text { and virtual } \\
\text { enterprises: } \\
\text { issues and } \\
\text { challenges for } \\
\text { transition } \\
\text { economies } \\
\text { Lefebvre, L.A., } \\
\text { Lefebvre, E., } \\
2002 .\end{array}$ & $\begin{array}{l}\text { Common } \\
\text { Messaging } \\
\text { Infrastructure }\end{array}$ & $\begin{array}{l}\text { Sharing of } \\
\text { transactional, } \\
\text { contractual or } \\
\text { technical } \\
\text { information } \\
\text { necessary to } \\
\text { the design, } \\
\text { manufacture } \\
\text { and sale of the } \\
\text { product }\end{array}$ & $\begin{array}{l}\text { Accounting } \\
\text { Logistics }\end{array}$ & $\begin{array}{l}\text { "But if I received single enumeration, or somehow details of the transactions, then I } \\
\text { have no problem paying the bills monthly." } \\
\text { "The order will be put it in a carrying bag and they take it with them." }\end{array}$ \\
\hline $\begin{array}{l}\text { An e-business } \\
\text { integration and } \\
\text { collaboration } \\
\text { platform for } \\
\text { B2B e- } \\
\text { commerce } \\
\text { Bhaskaran et } \\
\text { al., } 2001\end{array}$ & $\begin{array}{l}\text { Solution } \\
\text { Management \& } \\
\text { Monitoring }\end{array}$ & $\begin{array}{l}\text { Facilities for } \\
\text { audit logging, } \\
\text { tracing, and } \\
\text { exception } \\
\text { handling }\end{array}$ & $\begin{array}{l}\text { Merchandise } \\
\text { management } \\
\text { Customer } \\
\text { monitoring } \\
\text { Products } \\
\text { monitoring }\end{array}$ & $\begin{array}{l}\text { "SAP IC 12, I believe." } \\
\text { "We are currently aware of larger number of orders in the Christmas business, because } \\
\text { we also prepare a lot of shipping for companies that give us all the customer data, and } \\
\text { then we send the presents out." } \\
\text { "As I said, Rosé only works in summer, now when it gets cooler it just does not work." }\end{array}$ \\
\hline $\begin{array}{l}\text { Trust } \\
\text { requirements in } \\
\text { e-business. } \\
\text { Jones, S., } \\
\text { Wilikens, M., } \\
\text { Morris, P., } \\
\text { Masera, M., } \\
2000 \text {. }\end{array}$ & $\begin{array}{l}\text { Delivery of } \\
\text { goods }\end{array}$ & $\begin{array}{l}\text { Delivery of the } \\
\text { ordered } \\
\text { product through } \\
\text { the online } \\
\text { business } \\
\text { platform }\end{array}$ & $\begin{array}{l}\text { Recent delivery } \\
\text { system } \\
\text { Specific delivery } \\
\text { instructions }\end{array}$ & $\begin{array}{l}\text { "Meanwhile, we deliver the products every day, except on Saturdays. Four or five } \\
\text { delivery trucks are used now." }\end{array}$ \\
\hline $\begin{array}{l}\text { E-commerce } \\
\text { and virtual } \\
\text { enterprises: } \\
\text { issues and } \\
\text { challenges for } \\
\text { transition } \\
\text { economies } \\
\text { Lefebvre, L.A., } \\
\text { Lefebvre, E., } \\
2002 \text {. }\end{array}$ & $\begin{array}{l}\text { (After-sales) } \\
\text { Service and } \\
\text { technology }\end{array}$ & $\begin{array}{l}\text { Additional } \\
\text { service } \\
\text { provided for } \\
\text { customers }\end{array}$ & $\begin{array}{l}\text { Preparation time } \\
\text { for a delivery } \\
\text { Customer } \\
\text { complaint } \\
\text { Rating/feedback } \\
\text { system }\end{array}$ & $\begin{array}{l}\text { "That depends, if I work here on a Saturday anyway and there is a lot thing to do. The } \\
\text { preparation of the order will take longer than a Monday, when there is not so much } \\
\text { customers in the store. But I think the job is done in half an hour." } \\
\text { "The complaints are handled directly. We also have no problems; the customer is } \\
\text { always right." }\end{array}$ \\
\hline
\end{tabular}

Source: Own research, based on results of qualitative content analysis

\section{Findings}

In the following, we first point out where retailers need assistance to innovate their business models towards the ability of participating in online platforms while summarizing the current business models. Second, we describe in detail the actual status quo of the retailers' business models. Third, an overview about technological and non-technological requirements in the case of implementing digital platforms in small owner managed grocery retailing is given (see Figure 1). 


\section{Figure 1: Research Framework}

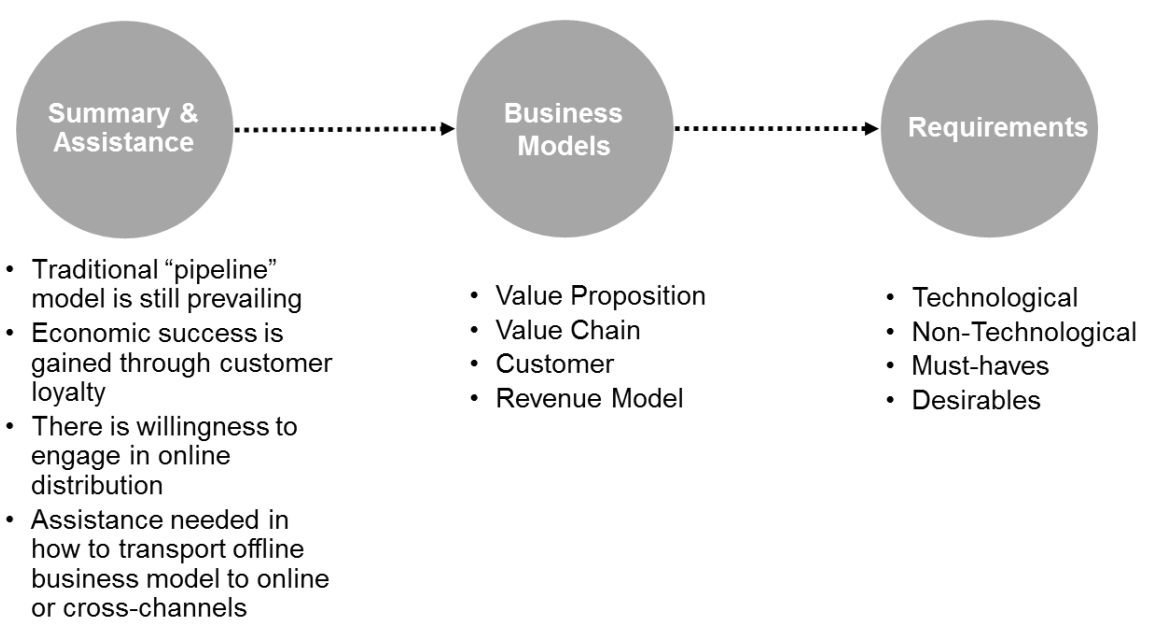

Source: Own figure, based on results of qualitative content analysis

\subsection{Summarizing Business Model Assistance}

Figure 2 summarizes the findings on the interviewed retailers' business models in terms of the needed assistance when engaging in online platforms. A written analysis is following subsequently. To gain a more comprehensive insight, the details of the actual business models are examined in 4.2.

\section{Figure 2: Grocery Retailers' Need for Assistance}

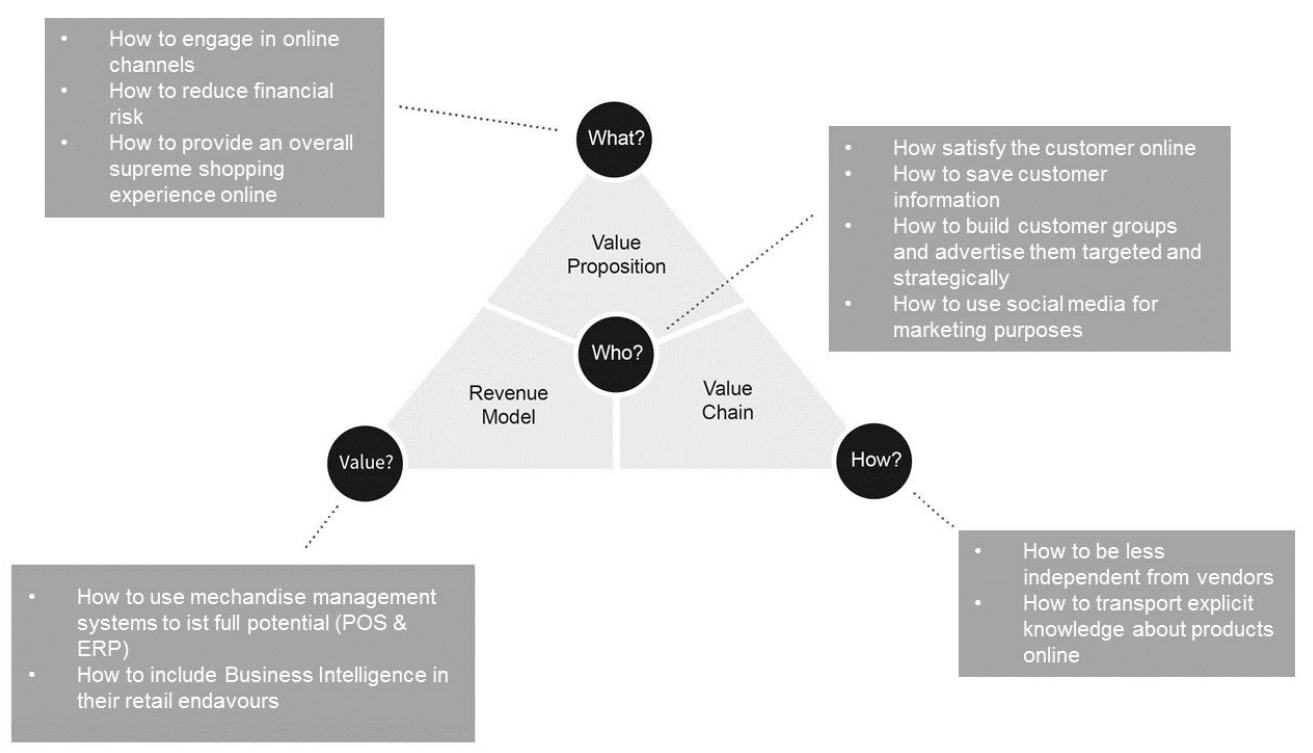

Source: Own figure, following Gassmann et al. 2013 
Summarizing the examined business models of the interviewed retailers, we derive that stationary grocery retailers still reach their customers through a traditional "pipeline" model (Choudary 2015; Parker et al. 2016; Van Alstyne et al. 2016).

Most of the interviewed retailers do not use digital tools to improve their customer understanding and customer relation management. We also discovered that most interviewed retailers do not have specific target groups, which leaves the potential of their explicit knowledge, especially about loyal customers unfulfilled.

$71 \%$ of the retailers utilize point of sale systems (POS) and enterprise resource planning (ERP) systems, but only to receive a rough overview of the inventory (one interviewed gourmet food store states "Until know it was not necessary that I track the inventory correctly [...]. Another interviewed butcher explains that he does not know what POS or ERP Systems are and states, "This is all a matter of feeling and experience"). Most of the retailer do not know how to use POS and ERP systems in detail resulting in unused potentials for e.g. an optimal inventory level for each item, customer service in terms of delivery speed, cost, product quality etc.(Smith \& Agrawal 2000). Stated challenges e.g. the risk of overproduction, saver forecasts of consumption and how to attract more customers, can be overcome by using POS or ERP systems. To learn how to use these opportunities they hold, retailers need assistance (Terziovski 2010). Support is required in operating the saved data in order to understand inventory track and trace in real time, as well as analysing consumer data and apply the results to the own retail.

$100 \%$ of the interviewed retailers are willing to engage in online distribution channels. It is noticeable that the degree of engagement in online endeavours is related to the own technical openness and ability, but less to their age. The estimate of the technical ability of the retailers is based on subjective perceptions that were gained during the interviews. $92 \%$ of the interviewed retailers wish for click and collect functionalities. Through this, as well as their current engagement in online efforts (50\% are providing an online shop), we observed a tendency to establish cross-channels, which enables customers to order products through different ways, such as in-store and online. Nevertheless, the interviewed retailers expressed, that a solely online shop or presence is not economically profitable. One retailer (a butchery) already engaged in online retailing five to ten years ago but closed the online shop down due to missing success (the butchery states: "10 years ago we had an online-shop and then we discovered that it is really difficult to sell meat online. We think this is because meat is a product that the customer wants to see"). Several retailers admitted, that they only engage in online retailing for the fear of being left behind, even though the online business is not profitable currently (a full range supermarket states: "Right now we do not make any profits with the online services. Right know we hope that the experiences that we gain e.g. what products do consumers buy, how far away are they living, will be useful") 


\subsection{Status Quo of the Examined Business Models}

In the following we examine the status quo of the business models following the structure of the business model navigator by Gassmann. In Figure 3 an overview of the key findings is given.

\section{Figure 3: Key Business Model Status Quo - Key Findings}

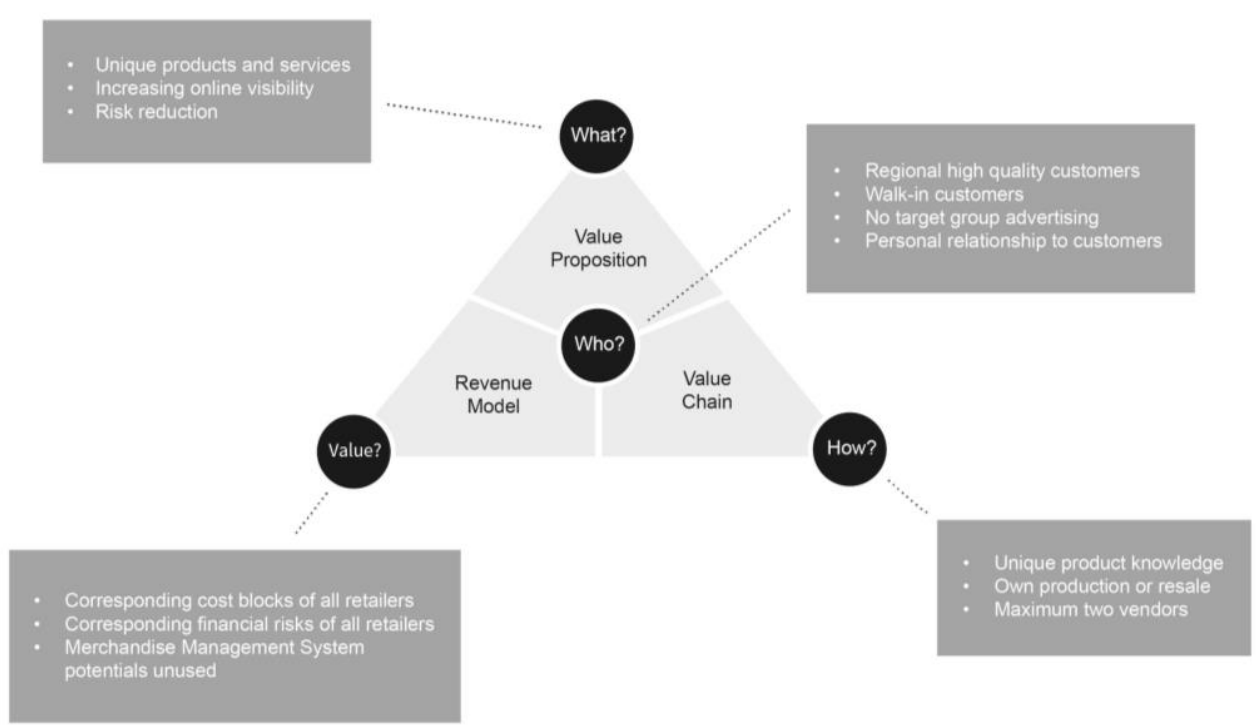

Source: Own figure, following Gassmann et al. 2013

\section{Value Proposition - What do the retailers offer to the customer?}

$100 \%$ of the retailers are focussing on providing their customers an excellent, unique service throughout the entire sale process resulting in the goal to provide all customers an overall supreme shopping experience (an exemplary answer of a queried butcher: "I'll try to give the customer a reason why he has to visit my store. [...] The products that customers can buy at our shop you cannot buy anywhere else"). This strategy is used to remain competitive against other retailers in the grocery market, where the business models are mostly identical. $100 \%$ of the retailers point out that the product quality is the most important factor for their overall service quality. High quality products and services in combination with a comfortable service convenience are seen as their Unique Selling Proposition (USP).

In total, twelve retailers are offering traditional stationary trading and sell their products via their physical retail shop. In terms of establishing online shops, we observed that seven (50\%) retailers expanded their traditional business with an own online shop accessible via website (no App). Two of them solely focus on online trade. The motivation of the interviewed retailers, whether conducting the strategy to focus on specialities, niches or the multi-channelling approach, is ultimately to reduce financial risks. 


\section{Value Chain - How is value created?}

The offered products are either supplied by vendors $(76 \%)$ or are produced by the retailer itself (24\%). The vendor structure of the interviewed retailers, both, producer or distributors shows similarities. Most of the vendors are either medium-sized and regional $(28 \%)$, German wholesale trades $(35 \%)$ or foreign importers $(28 \%)$. Nearly half of the retailers have only one or two vendors which constitutes high dependence on their vendors.

In offering unique products, the knowledge about these niche products is of fundamental importance for the retailers. To acquire this knowledge an intense network of experts has to be build up. In addition, a careful product selection has to be conducted both on the side of the ingredients to produce the products as well as on the resale of specialities. Since this knowledge is one of their core competencies the interviewees are shy on explaining how to achieve it. At the same time, they proudly present their explicit knowledge of the taste, ingredients, origin and production of each single product. The knowledge of each employee as well as their close connection to vendors are the key resources in creating their value proposition.

\section{Customer - Who is the retailers target customer group?}

The customer is the centre of each of the grocery retailers' business model. All retailers state that the loyalty of their customers is of major importance for sustainable economic success (Hallowell 1996) (the queried fish trade states: "satisfied customers are those you want to have. Satisfied customers tell others about you and so your customer group growths"). The target customer groups of the interviewed retailers are consisting of walkin customers, which are usually regional and cannot be assigned to specific sociodemographical factors, gourmets, customers with low price sensitivity and corporate customers. The group of gourmets, is mentioned most often $(60 \%)$ and seen as one of the most important customer group, since they are able to value the quality of their products and willing to purchase the products on a regular basis.

All of the retailers communicate with their customers on a spoken level and use their personal feedback for service purposes. $50 \%$ of the interviewees save information about their customers, which include e-mail addresses for newsletter or mailings as well as their names. Information about shopping behaviour and favoured products is not saved. Diverging from private customers, the information about B2B customers are stored in some cases for advertising purposes, due to the fact that corporate consumers are willing to purchase larger orders. Only $7 \%$ of the retailers are strategically identifying customer groups by observing, how certain advertising efforts affect certain groups of customers. $78 \%$ of all intervieweed retailers are using a default online rating system via Facebook. Moreover, retailers offer additional services and special offers offline and via their social 
media channels in order to attract new customers and transform them into customers of high loyalty, allowing for increased profit (Hallowell 1996).

Due to small monetary resources, retailers are not utilizing any marketing actions to obtain more customers. Using social media resources therefore is an option to acquire more customers. With engaging in these marketing channels, retailers use a limited amount of financial resources, since those portals can be used for free. Personal resources for these marketing activities still have to be available but the extend of employability in marketing activities can be scaled.

\section{Revenue Model - How is revenue created?}

The revenue models of all interviewed retailers are almost identical. The main cost blocks contain personnel costs, cost of goods sold, lease costs and depreciation costs as well as all retailers generate their revenue solely through sale of goods.

Furthermore, $71 \%$ of the interviewed retailers use a merchandise management system to track the remaining inventory, which is not used to its full potential. The interviewed retailers do not check information about possible sales volumes throughout the day to optimize their production. But, in order to conquer the risk of overproduction or product unavailability, the usage of their experiences in the past has been exposed as the reliable criterion to coordinate their production and possible outsourcings. 33\% of the retailers check their revenues daily, $50 \%$ of the retailers check sales numbers and costs from a weekly to a monthly or even quarterly basis. The financial risks of overproduction, absence of customers, products availability through certain time periods, possible dependency on the vendors or low margin on certain products are named as the main financial risks and challenges.

\subsection{Technological and Non-Technological Requirements}

In the following, a listed report of the technological and non-technological requirements that were formulated by the interviewees is given. We present them by dividing them in must-haves and desirables (see Figure 4).

Looking at technological as well as non-technological requirements the range of requirements results in a widespread picture concerning the degree of concreteness in their requirements, which have to be seen in conjunction with their personal technical affinity. Factors were classified as must-have when either all retailers pronounced one specific factor as wanted or when one retailer depicted one specific factor as a must in order to be able to sell products online. Must-have requirements thereby declare the factors that have to be fulfilled in order to implement and operate a digital platform with small owner managed grocery retailers. Desirable requirements are functionalities that are not necessarily required when participating in a digital online shopping platform for groceries. 
Figure 4: (Non)-Technological Retailers Requirements Technological

- Provide timeframe for preparation depending on in store traffic

- Click and collect functionality

- Deadline for online orderings for same day delivery

- Delivery of products in hygienic condition

- Announcement of moment of delivery

- Tracking of uniterrupted cold chain during delivery

- Undamaged delivery

- Time frame for courier to return rejected products

- Opportunity of continuously product information Updates

- Display purchase order price depending on the weight of the content

- Rating systems of retailer and products

- Guarantee age control (e.g. alcohol)

- Interface/API to already existing OnlineShops

- Financial exchange with the platform once per month

- Facilitate revenue forecast for recognizing best-selling products in different periods of time and identifying possible shortage or critical mass on products

- Send email notifications if one product is sold out, automatic reorder of products

- Transaction number for each order so that each order can be tracked and traced (no wrong deliveries)

- (Transparent) documentation of complaints to avoid them in future
Non-Technological

Click and Collect: store needs to provide physical infrastructure

- Hygienic areas are not allowed to enter by the courier

- Uncomplicated handover of the ordered products from retailer to courier and from courier to customer

- Cold chain management during delivery (meat 6 degrees, fish and frozen 2 degrees)

- No hand over to the courier with fresh foods right out of cooling area, which could affect other products in the cooling area Warm products must stay warm

- Customer must have the option to reject products when delivered

- No discussion with customer, termless replacement

- All kinds of customers should be addressed via the platform

- Own cooling unit for deliveries is wanted

- Additional care with some products that are sensitive to damage

- Delivery of vegan products not in the same bag as meat

- Personal hand over of the courier when delivering to special customers

- Fulfil every need of customer to make him feel happy and emotionally bound to its favourite retailer

- Keeping up personal communication

- Product handover should be progressed as soon as courier enters the store

Source: Own research, based on results of qualitative content analysis

Looking at the must-have requirements, the results show that the delivery process is a crucial factor when disposing grocery via internet. $70 \%$ of all must-have requirements can be assigned to the delivery process. Especially the handover for delivery as well as the careful treatment of the products is of great interest. Hence, grocery retailers want to guarantee a convenient service in the delivery process for the customer, which is reflected by the requirement of uncomplicated handover as well as a save, quality maintaining delivery. In this context, it is also astonishing, that the termless return of products is wished from all of the retailers. The must-have requirements show, that the factors strongly connected to customer satisfaction, are of major importance. The retailers want to guarantee their customers a likewise positive online shopping experience, compared to shopping offline in their stores. Therefore, they try to translate their main offline USP and value creation activities to digital purposes.

Assessing the desirable, non-technological requirements we likewise observe a focus on the delivery process as well as the wish to translate their offline business model with only 
slightly changes to a digital business model. In technological terms, we recognize the requirement to simplify the purchasing and administration process of online sales as well as the demand of linking these processes to the offline disposal process e.g. transaction number for each order to track and trace, automatic reordering, revenue forecasts. The investigated factors with respect to non-technological requirements appear to be more individually needed by only a few of the retailers, demonstrating the small but significant differences in the business models of the grocery retailers.

\section{Conclusion and Discussion}

The digitalisation undeniably forges the process of market restructuring ahead. Therefore, the aim of this paper is to provide practical insides from real case studies and thereby examine and understand the status quo of grocery retailers' business models in Germany as well as their limitations. Moreover, we explore technological and non-technological requirements of small grocery retailers when opening up their business model to the engagement in online platforms. Insights to research and practice on how digital platforms for small owner managed grocery retailers can be successfully implemented are provided.

In order to stay competitive in the future, we believe that local retailers should establish their online presence and integrate cross-channels in order to ensure their future market position. Nevertheless, operating an own online shop also requires additional human resources to prepare the online ordered products and maintain the shop, which consist of necessary product information update or debugging technological failures.

Due to the unknown probability of success, investing in additional human resources has not been undertaken so far (Falkner \& Hiebl 2015). While only half of the retailers save the information about customers for advertisement purposes, almost all of the retailers track their business processes like revenue or cost to obtain an overview about the current business status. If this data is observed over a timespan, experiences can be gained. These insights can for example be used for further predictions in production or revenue forecasting in seasonal businesses. Consequently, retailers can offer their products more targeted. This reduces the risk of overproduction. Simultaneously they improve the degree to which they are able of fulfilling customer needs. Thereby customer loyalty intensifies, which in turn leads to sales growth. Furthermore, loyalty and trust is already been explored to play a key role in e-commerce resulting in an increase in sales (Fedoseeva, Herrmann \& Nickolaus 2017).

Named challenges can be overcome by engaging in a regional grocery platform that is operated by a third independent party. Applying platform models in the sector of online grocery retailing creates possibilities to generate more revenue for retailers. The so called network effects evoke long term retention on both sides of the platform (retailer and consumer), thereby increasing repetitive shopping behaviour and resulting in sales 
growth (Choudary 2015). The merge of grocery retailers on a regional basis allows them i) to attract customers by providing the advantage of combined shopping carts, ii) to use an external logistics provider while the delivery process is automatically integrated to the online platform iii) to use business analytics tools, iv) to cover the regional online share of grocery online shopping while being able to compete against big supra-regional players, v) to open up their existing business model to a cross-channel approach by simultaneously operating their stationary traditional business.

\section{Limitations and Further Research}

On the local level, retailers' profit from the values, which are created via platform, but it has its limitations on national level. If a large number of retailers participate in the platform, customers could be irritated by the variety of retailers to purchase from. Additionally, the logistics will become more complex to cover, especially in regard to the special requirements of delivering fresh foods. Further research should therefore find out the maximum platform size in grocery retailing, whether a maximum number of retailers or number of products exist, or if grocery platforms are only economic efficient applicable on a regional level.

In further research, hidden needs on both sides including retailers and customers should be detected. To explore and deepen the understanding of retailers' requirements concerning business models, we currently perform Business Canvas Workshops as well as requirement workshops through which the retailers' requirements can be understood on a deeper level. We also observe retailers while using a grocery online platform prototype to gain more experiences in their requirements on practical realisation. To oppose them to the hidden needs of consumers, which are the centre of profit creation in retailing, we also engage in an in-depth survey as well as the methodology of ethnography.

Further research should determine the relative importance of the desirable requirements, through a quantitative research method, which allows an analysis of larger samples. Besides, the technological knowledge of the retailers should be explored in more detail to predict further development of their online businesses as part of the business model.

Further research could also engage in the impact on competitive behaviour among the retailers when participating in platforms. It is of interest if regional platforms modify the economic structure of the region through the via platform given better price transparency. It should be considered that consumer savour low costs when accumulating product information e.g. price especially in digital times. Simultaneously, it is advantageous for retailers having lower costs in collection information about their customers. With the via platforms easier to acquire information about their customers, retailers can customize their customer advertising strategies. Through this retailers find themselves in a situation 
where different retailers make profits, even when same products are offered by different retailers with different prices (Fedoseeva et al. 2017).

\section{Acknowledgements}

This research was conducted as part of the research project called smart emma. The project is funded by the EU and the European Fonds for regional development (EFRE.NRW). We warmly thank the participants of the survey for supporting the project. Also, we would like to extend our deepest gratitude to our colleagues from IMA (RWTH Aachen University), Teleretail GmbH (Düsseldorf, Germany) and Neomesh $\mathrm{GmbH}$ (Aachen. Germany) who made contributions to the design of the survey. The project smart emma is a joint, national project of IfU (Institute on Management Cybernetics at RWTH Aachen), IMA (Chair of Information Management in Mechanical Engineering, RWTH Aachen University), Teleretail and Neomesh.

\section{References}

Akhter, S.H., 2012, 'Who spends more online? The influence of time, usage variety, and privacy concern on online spending', Journal of Retailing and Consumer Services, 19(1), 109-115.

Bettina Borchmann, 2018, Der Lebensmitteleinzelhandel im Wandel.

Bhaskaran, K., Chung, J.-Y., Das, R., Heath, T., Kumaran, S. \& Nandi, P., 2001, An e-business integration and collaboration platform for B2B e-commerce, Advanced Issues of E-Commerce and Web-Based Information Systems, WECWIS 2001, Third International Workshop on., 120-122, IEEE.

Cao, L. \& Li, L., 2015, 'The Impact of Cross-Channel Integration on Retailers' Sales Growth', Journal of Retailing, 91(2), 198-216.

Cervellon, M.-C., Sylvie, J. \& Ngobo, P.-V., 2015, 'Shopping orientations as antecedents to channel choice in the French grocery multichannel landscape', Journal of Retailing and Consumer Services, 27, 3151.

Chesbrough, H., 2007, 'Business model innovation: it's not just about technology anymore', Strategy \& Leadership, 35(6), 12-17.

Chesbrough, H., 2010, 'Business Model Innovation: Opportunities and Barriers', Long Range Planning, 43(2-3), 354-363.

Chiou, W.-C., Lin, C.-C. \& Perng, C., 2011, 'A strategic website evaluation of online travel agencies', Tourism Management, 32(6), 1463-1473.

Choudary, S.P., 2015, Platform Scale: How an emerging business model helps startups build large empires with minimum investment, First, Platform Thinking Labs.

Church, J. \& Gandal, N., 1992, 'Network effects, software provision, and standardization', The journal of industrial economics, 85-103.

Eisenhardt, K.M., 1989, 'Building theories from case study research', Academy of management review, 14(4), 532-550. 
Evans, P.C. \& Gawer, A., 2016, 'The rise of the platform enterprise: a global survey'.

Falkner, E.M. \& Hiebl, M.R., 2015, 'Risk management in SMEs: a systematic review of available evidence', The Journal of Risk Finance, 16(2), 122-144.

Fedoseeva, S., Herrmann, R. \& Nickolaus, K., 2017, 'Was the economics of information approach wrong all the way? Evidence from German grocer r(E)tailing', Journal of Business Research, 63-72.

Flick, U., 2014, An Introduction to Qualitative Research, SAGE.

Ganesh, J., Reynolds, K.E., Luckett, M. \& Pomirleanu, N., 2010, 'Online shopper motivations, and e-store attributes: an examination of online patronage behavior and shopper typologies', Journal of retailing, 86(1), 106-115.

Gassmann, O., Frankenberger, K. \& Csik, M., 2013, Geschäftsmodelle entwickeln: 55 innovative Konzepte mit dem St. Galler Business Model Navigator, Carl Hanser Verlag GmbH Co KG.

Gawer, A. \& Cusumano, M.A., 2008, 'Platform Leaders', MIT Sloan management review.

Hagiu, A., 2009, 'Two-sided platforms: product variety and pricing structures', Journal of Economics \& Management Strategy, 18(4), 1011-1043.

Hallowell, R., 1996, 'The relationships of customer satisfaction, customer loyalty, and profitability: an empirical study', International journal of service industry management, 7(4), 27-42.

Handelsverband Deutschland, 2017, 'Handelsreport Lebensmittel Online’.

Iyer, G., Soberman, D. \& Villas-Boas, J.M., 2005, 'The Targeting of Advertising', Marketing Science, 24(3), 461-476.

Jones, S., Wilikens, M., Morris, P. \& Masera, M., 2000, 'Trust requirements in e-business', Communications of the ACM, 43(12), 81-87.

Kang, C., Moon, J., Kim, T. \& Choe, Y., 2016, Why consumers go to online grocery: Comparing vegetables with grains, 2016 49th Hawaii International Conference on System Sciences (HICSS), 3604-3613, IEEE.

Keller, R., Hirseland, A., Schneider, W. \& Viehöver, W., 2011, Handbuch sozialwissenschaftliche Diskursanalyse, VS Verlag, Wiesbaden.

Lefebvre, L.A. \& Lefebvre, E., 2002, 'E-commerce and virtual enterprises: issues and challenges for transition economies', Technovation, 22(5), 313-323.

Linder, J. \& Cantrell, S., 2000, 'Changing Business Models: Surveying the Landscape', accenture Institute for Strategic Change.

Marshall, B., Cardon, P., Poddar, A. \& Fontenot, R., 2013, 'Does sample size matter in qualitative research?: A review of qualitative interviews in IS research', Journal of Computer Information Systems, 54(1), 11-22.

Mayring, P., 2010, Qualitative Inhaltsanalyse: Grundlagen und Techniken, Beltz.

Melis, K., Campo, K., Breugelmans, E. \& Lamey, L., 2015, 'The impact of the multi-channel retail mix on online store choice: does online experience matter?', Journal of Retailing, 91(2), 272-288. 
Moriuchi, E. \& Takahashi, I., 2018, 'An empirical investigation of the factors motivating Japanese repeat consumers to review their shopping experiences', Journal of Business Research, 82, 381-390.

Osterwalder, A., Pigneur, Y. \& Tucci, C.L., 2005, 'Clarifying business models: Origins, present, and future of the concept', Communications of the association for Information Systems, 16(1), 1.

Parker, G.G., Alstyne, M.W.V. \& Choudary, S.P., 2016, Platform Revolution: How Networked Markets Are Transforming the Economyand How to Make Them Work for You, W. W. Norton \& Company.

Raj, S.P., 1982, 'The Effects of Advertising on High and Low Loyalty Consumer Segments', Journal of Consumer Research, 9(1), 77-89.

Sheth, J.N., Sisodia, R.S. \& Sharma, A., 2000, 'The antecedents and consequences of customer-centric marketing', Journal of the Academy of marketing Science, 28(1), 55-66.

Smith, S.A. \& Agrawal, N., 2000, 'Management of Multi-Item Retail Inventory Systems with Demand Substitution', Operations Research, 48(1), 50.

Suel, E., Le Vine, S. \& Polak, J., 2015, 'Empirical application of expenditure diary instrument to quantify relationships between in-store and online grocery shopping: case study of Greater London', Transportation Research Record: Journal of the Transportation Research Board, (2496), 45-54.

Terziovski, M., 2010, 'Innovation practice and its performance implications in small and medium enterprises (SMEs) in the manufacturing sector: a resource-based view', Strategic Management Journal, 31(8), 892-902.

Tontini, G., Silva, J.C. da, Zanin, E.R.M., Beduschi, E.F.S. \& Marcon, M. de F., 2018, 'Corrigendum to Identifying Opportunities for Improvement in Online Shopping Sites [Journal of Retailing and Consumer Services, volume 31 (2016) 228-238]', Journal of Retailing and Consumer Services, 42, 175.

Van Alstyne, M.W., Parker, G.G. \& Choudary, S.P., 2016, 'Pipelines, platforms, and the new rules of strategy', Harvard business review, 94(4), 54-62. 